\title{
Socialist Transformation is an Important Event in the History of Chinese Socialism
}

\author{
Kangjian Shi \\ Shenzhen Institute of Information Technology
}

(Shenzhen, China 518172)

Keywords: Socialist transformation; Redemption; Collective cooperation; Industrialization

\begin{abstract}
The socialist transformation has been more than 60 years' history, it is a very important event in the history of international communist movement, and it faithfully practice the Marx doctrine on thought of the success of the democratic revolution to socialist unfolding transition to make years' of dream of socialism into reality. We review the history of our party today in-depth study of early exploration China tortuous course of socialism with the objective evaluation and understanding of the socialist transformation, and this paper will have a positive impact on our future development of socialism.

Socialist transformation is the most wonderful leap from the new democratic society to socialist society for China, and it is the most creative way to explore the form of Chinese socialism, and it plays an important role on changing the transformation of Chinese socialism. First of all, it is based on Lenin's "under certain conditions, workers will not refuse to redeem”, to the bourgeoisie, in order to save the production organization, to socialism with civilization and organization , capitalist "to pay higher prices to their redemption, and this idea is completely acceptable." After the completion of the democratic revolution in a capitalist rule base which is relatively weak on the state of the Chinese bourgeois property was successfully split redemption, the bourgeoisie integrated into the "club", and from theory and practice, it achieves a "deprives"; secondly, from the direct effect of socialist transformation, the political significance is very large, it not just has achieved an important social change, and it is more important to expand the system influence to the whole society making socialist ideology more deeply, so that thought of "only socialism can save China” is deeply engraved in people's mind, thus it strengthened the people go the socialist determination road. Thirdly, it strengthens the national unity, and the Socialist unites the will of the people with the stability of the country just restore social order, which contains political wisdom that still has a positive reference for today's socialist cause ${ }^{[1]}$
\end{abstract}

\section{Socialist Transformation is an Important Bridge for the Transition from a new Democratic Society to a Socialist Society}

After the success of the new democratic revolution, the most important issue in front of the Chinese Communist Party is how to get into socialism as soon as possible. According to the Marx doctrine on the future of social ideas, there is a transition period between capitalism and communism, in this transition period, it will complete the conversion of the bourgeois character, the exploiters, the old society managers come into the new society of ordinary workers, private property through confiscation or redemption way to convert all countries or all public, the whole society will be administered by the proletariat, and the majority of workers and peasants will become the real owner of society. After the end of the transition period, the first stage of communism comes. ${ }^{[2]}$ In the transition period of time, the classical theorists did not give specific arrangements, it can be 10 years, 20 years, or even longer, and this depends on the specific practical results. Before and after 1951, the party generally formed the first five years with three plans to engage in industrial construction and the accumulation of conditions, and then to the socialist transition consensus. In the condition of changing, they think that only the achievement of national industrialization can 
achieve private industrial nationalization and collectivization of agriculture; and on the aspects of steps in the transition, when industrial development, when the state economy growth, we can further implement capitalist nationalization and individual agricultural collectivization. In a meeting of the Political Bureau of the party held in the second Plenary Session of the 7th CPC Central Committee, Zedong Mao proposed that after the won victory of new democratic revolution in the whole country, but also about the need after 10 years, 15 years or 20 years to re envision of the transition to socialism. This idea is mainly based on the following considerations: first, China is a long-term country with agricultural production as the leading industrial, and the foundation is relatively weak which means the development of industrialization and improve the level of productivity is not a short duration of time things, and it takes some time, there are needs to be a process of quantitative change to qualitative change; secondly, China is a a multi-ethnic and multi-religious country, it has different thoughts, and in order to make different voices are twisted together, it should put up on the big stage of a socialist with requires of a process of guidance and organization; thirdly, the residual hostile forces may collude hostile foreign forces to destroy the new China in the construction, hindering the construction pace, this will delay the implementation stage of the goal of economic construction. Fourthly, some negative factors should go through domestic competition with the positive factors in the growth of positive factors to become the leading social force that needs a process; While later situation was unexpected, it was not 10 years and not 15 years, but only 7 years time, we successfully transfer from the new democratic society to socialist society, and the socialist revolution has made an important breakthrough. The acceleration of this process is the transformation of socialism. According to the experience of Soviet socialism, the standard of entering socialism is only two, one is the dictatorship of the proletariat, and the other is public ownership. Before the socialist transformation, China's constitution has been basically established, we are the people's democratic dictatorship, that is to say, the before one is qualified, but the another is unqualified which is the need to continue efforts to create conditions. According to statistics, before the transformation that is in 1952, China's total industrial output value of the proportion of public and private is $67.3 \%$ to $32.7 \%$, and the proportion of private business in the country's total value of goods is $37.1 \%$, and in the city, it accounted relatively high[2]. Obviously, the state-owned economy has occupied a considerable advantage in the country's economic life, but it has not reached the goal of the development of the private industrial and commercial enterprises. We transformed by powerful policy advantages and continued to expand the scope and scale of public-private partnerships in order to narrow the development space of private capital with the assistance of the Soviet Union, and it actively carried out industrial and agricultural layout in the country set up several large industrial base, such as FAW, Anshan, Wuhan are at the Soviet Union under the guidance of experts that set up. At the same time, we explore the establishment the representative of the super large national grain production base in the border in the Great Northern Wilderness, in order to solve the problem of shortage of food and agricultural products in the construction industry. With the gradual deepening of the socialist transformation of capitalist, the proportion of private economy in the national economy is more and more small, the total industrial output value in 1956, compared with 1952, the industry increased from 56\% to $67.5 \%$, the national capitalist industry increased from $26.9 \%$ to $32.5 \%$. The capitalist industry fell from $17.1 \%$ to near zero. In retail sales, the State Commerce and supply and marketing cooperatives also increased from $42.6 \%$ to $68.3 \%$, state capitalism commercial and from the original small firm organization cooperation business increased from $0.2 \%$ to $27.5 \%$, the private business decreased from $57.2 \%$ to $4.2 \% .{ }^{[3]}$ This shows that the system of class exploitation, based on the private ownership of the means of production has been basically wiped out in China for thousands of years, and the socialist economic system based on the public ownership of the means of production has been established. In the recovery period of national economy, some unscrupulous capitalists had used our regime that was not stable, not too familiar with the national market, making waves in the market, and a large number of hoarding food, cloth, price gouging, bring some difficulties to the lives of people, 
especially the commodity economy that has more developed in Jiangsu, Zhejiang and Shanghai area where is the most serious. And the capitalists borrow from the Korean War used in the production of shoddy work, filled with bad, adulteration false means, and the production of inferior materiel, such as fake fake fake grenades, first-aid kit, penicillin. After different strikes, such as help and Education -- the punishment, warning, most capitalists began to recognize the consciousness. Only through legitimate means, legitimate business, take the road of socialism is a way to go out from dilemma. This is an improvement of the national bourgeoisie. Now, if there is no socialist transformation on the agriculture, handicraft industry and capitalist industry and Commerce, but allows it to stay in the new democratic period for a long time, it will slowly circulated at the limit and strike, and support of the national bourgeoisie which lets the peasant economy and small handicraftsmen spread, so the result may be the state-owned economy up, private economy, peasant economy, small handicraftsmen will slowly rise. Because of these economic sectors grew from the soil in the old system, there are inextricably linked and old China, especially some large national bourgeoisie have at least a few decades or even more than 100 years of history, they know the market, understand the business, and most industrial products still rests in their hands, once they the formation of economic advantages, they will rely on the market, brand and price monopoly of state-owned economy and tools to summon wind and call for rain resistance to increase the difficulty of reformation, and even refused to reform. So peaceful redemption may evolve as the final imaging Russian national bourgeoisie that can only be solved problems by means of war, the people's democratic dictatorship will be a class united to set up new challenge. In fact, later in 1957 anti rightist, representatives of many of the national bourgeoisie and the Communist Party to challenge the public to jump out with the fierce enough to prove this point. Led by Zedong Mao, the party's first generation of leaders after careful consideration in the range of controllable contradiction in a timely seize the successful transformation of this historical opportunity, do not stop, do not stop, resolutely guide people across the country from the new democratic society entered the socialist society which has opened up a new page in the history of China.

\section{Socialist Transformation is a Great Socialist Education Movement}

The socialist transformation has only a short period of three years in practice, but its meaning is very great, and it not only make Chinese come quickly into socialism, it is more important for people to accept China have a profound political baptism. What is socialism? Most people do not understand, only a few people during the war by Marx's textbook, by the Soviet Union of visit and study to contact with Soviet Socialist, and more people are still stuck in the imagination on the basis of understanding of socialism. With the deepening of the socialist transformation, more and more people participate in the practice of socialism, and the experience of socialism is becoming more and more profound. Before the transformation, China has just completed the rural land reform and land re-distribution, many farmers in past generations have no land, and their life is to maintain by tsukuda, pay rent. Now with the free it achieved the "land to the tiller". The rural economy has been developing, but in the future how the way goes, each have their own ideas, and many people will start to get after the dream build up the family fortunes, and some people even think of how to become the new landlord land annexation of others. This is not the end of our democratic revolution. It is not only a political turn to lead the peasants to turn over their liberation, but also to guide them to take the socialist road, not to return them to the old society, to engage in polarization, and to take the old road of exploitation. Rural socialism, in the final analysis is to guide farmers to take the road of rural collective cooperation. At the beginning of reform, we have done a lot of preparatory work that includes sent a work team to the countryside, to carry out publicity and education to farmers, change new Chinese, speaking farmers in power experience, stimulate the peasants to build socialist determination, from mutual aid group, the primary agency to senior agency, rural completed three jumps into the socialist. From the past to go private, into the collective organization of production, 
the production of collective owned. The practice has proved that after the realization of agricultural cooperation in rural areas, the people's work enthusiasm has been greatly released, and the production and life has been greatly improved. Now, if we do not use the transformation in a timely manner to shorten the transition period of hundreds of millions of farmers who quickly lead to socialism, so that they not only in the political position, but also to turn in the economy, people's rising socialist enthusiasm will be diluted, and "only socialism can save China" will become an empty political slogan.

The success of the socialist transformation makes more people realize that the Communist Party of China is wise and great. In the past a lot of Democrats for the leadership of the Communist Party of Chinese doubts that engage in economic construction, although the Communist Party of the democratic revolution led to China success in battles and the Kuomintang in the contest, but it may not be able to lead economic construction. But with the gradual recovery of the national economy, with more and more great achievements of the socialist transformation, a furnace body, a railway was opened to traffic, some Democrats have changed the concept of the Communist Party had to sit up and take notice. They recognize that the Communist Party is different from the Kuomintang party, it does not seek personal gain, while it all for the sake of the masses of working people, and it punish corruption, uphold justice, treat the brothers parties to each other, but it is in perfect sympathy with each other and really do practical things for the people's party. Some Democrats have also been invited to serve as important leadership positions in the country which contributes to the development of new china.

The success of the socialist transformation, but also called a firm that any excellent overseas firm to take the road of socialism, they have to take. A lot of achievements during the China "the first one five years" all cannot do without the eve or the beginning of the founding of returned overseas talents, such as Siguang Li, Jiaxian Deng, Sanqiang Qian, Xuesen Qian and so on, these people have very good working conditions in foreign countries, according to their individual ability, after several years of efforts, there is likely to be the leader of a field in the world, but they eventually gave up. Why? It is socialism has been deeply printed into their minds, by China socialism save - it is their identity in the best way, not only can change China appearance, but also to achieve the pursuit of the value of your life. The success of the socialist transformation strengthened their determination to devote themselves to the cause of the motherland. Many of them joined the Communist Party of China and contributed their lives to the best cause of mankind.

The socialist transformation has aroused the enthusiasm of the minority nationalities in building socialism. Ethnic minorities are generally located in remote areas, living scattered, and the natural environment is relatively bad. In the old system, in addition to the ethnic minorities suffer feudal oppression and exploitation, but also by the numerous fraud bureaucrats, warlords, comprador, no right to speak on the political, and the economy is not independent, long-term labor productivity slash-and-burn cultivation. The relationship between ethnic minorities and ethnic minorities, as well as the relationship between ethnic minorities and the Han ethnic group is relatively tight. It is because of the socialist transformation, each nation unified guide to the socialist construction of the direction to replace the backward mode of production with advanced production methods with advanced culture and ideology to replace the backward culture thought to achieve the integration between the various ethnic groups. As Lenin said: "the aim of socialism is not only to destroy mankind into any state of isolation of many small nations and between different ethnic groups, not only to make the people close to each other, and to integrate the various nationalities". ${ }^{4]}$

In short, the socialist transformation of China's economy and society not only to complete the institutional changes in the ownership of the system, the more important is that it brings the entire Chinese nation in socialist ideological evolution.

Part Three the socialist transformation of our party strengthens the overstep of socialist point

At the first period of establishment of the People's Republic of China, in reality, the devastation of our party a thousand things wait to be done, very cautious attitude to the socialist transformation, 
the basic estimate is: 15 to 20 years later, and our country's industrial development has to a certain extent, "the case is transferred to the society". Zedong Mao said: "our country is so steady, after the war, after the new democratic reforms, and in the future, in the national economic and cultural undertakings are flourishing which has in various conditions, people in the country considered mature and later agreed to in the home, you can easily and properly to enter the new era of socialism". ${ }^{[5]}$ From the sentence itself, socialism is not an easy thing to do, it is to overcome many difficulties, and through the change of ownership, through the accumulation of material wealth, it takes 10 years, 20 years or even longer time. There is actually a problem of a time node. How to cross? It is not rash, and it can not wash their hands.

Since 1840, Chinese modernization shows that China is hesitation, indecision and miss the point chasing the western industrial civilization process for 100 years, the reason means that in addition to the system on the way, it is not always find a suitable for our national psychology, national culture, national style and national integration path of development, and in order to implement the national policy of colonialism in the world, capitalism is impossible for you to enjoy the same industrial revolution and his achievements not to provide advanced technology and management experience to you, but only to provide his goods or low-end consumer goods to you with using your market to earn excess profits. When you are familiar with his low-end products and can imitate manufacture, he also used the new technology to develop new products, and the manufacturing technology, his industrial tools is not always to you. So in the West behind to engage in capitalist industrialization, we will always be passive beaten, it will always be the dumping of their low-end products. Therefore, in the last century, the mid 50s to achieve the choice of national industrialization road, we can only choose socialism with new ideas and new ways to go beyond the west.

Lenin believes that the core of socialist construction is to achieve industrialization. Lenin pointed out: "the development of resources, the establishment of a socialist society is the only real and only one which is the big industry. If there is no big factory of capitalism, there is no highly developed large industry, it is simply not socialism, but for a peasant country that is even more so". ${ }^{[6]}$

Our country came out from the semi colonial and semi feudal society, the agricultural population accounted for more than $80 \%$ of the national population in the early period of liberation, just like Lenin said that our country is a peasant country. It is rather difficult to realize socialist industrialization in such a country with a very weak industrial foundation and a long-term development of agriculture. One is to develop the public sector of the economy and increase its proportion in the total economy, in fact, in 1952, China's economy of public ownership has been from 1949 in the total industrial output value accounted for $43.8 \%$ increased to $67.3 \%$, the speed of public ownership economy jumped quite fast; another is to speed up the socialist transformation to mobilize all positive factors walk the road of socialism. Zedong Mao stressed: do not forget that our country has a political condition, the political power in our hands, there is another economic conditions, the socialist economy is good. Now it is clear to the people that the productivity of socialism and semi socialist economy is greatly improved. The successful completion of the socialist transformation has proved this point. Initial transformation, people make emotional thinking, trying to use the principle of voluntary conflict to join cooperatives, even some farmers into the club to withdraw; some capitalists also openly jump out and required to maintain the order now, unwilling to accept the "gradual transition". However, later with the socialist transformation step by step, the general line of the transition period the party's ideological socialism became increasingly popular, the trend has been formed, some people thought slowly began to change over from the beginning of conflict conflict cooperatives, public-private partnerships to finally completely in favor of taking the socialist road. The accumulation of socialism is more and more big, and the power of capitalism is getting smaller and smaller.

The success of the socialist transformation, shortening the process of our socialist society, but also to avoid the time and time to enter the node on the hesitation and wandering, and it is entirely natural. It solves the problem of what road to take 100 years in China, what flag, the great historical 
significance. The road Chinese socialism opens on Chinese later played a leading role in a good, it is necessary to pay attention to the advantages of the socialist concentrating power, and it also can not ignore the people's relationship to the thousands of households living things which always put the development of productivity in the first place. Xiaoping Deng once pointed out: "our socialist transformation was a success. This is a great contribution of Comrade Zedong Mao to the Marx doctrine of the Chinese Communist Party of China." [7]

Socialist transformation is an important event in the historical process of China, it gives us a profound impression, and it makes from the beginning that we do not know what is socialism to know later what socialism is and how to build socialism, how to develop socialism. It allows us to understand: "to any one channel close to the Communist society from the capitalist society on the need of calculation and supervision such a transition to socialism, there is a long and complex transition (the less developed capitalist society, the transition time needed is longer)". ${ }^{[8]}$

\section{Reference}

[1] Selected works of Lenin Vol. third[M], Page 548 550

[2] Jingru Zhang, History of the People's Republic of China[M],Qingdao Publishing House(2009), Page 351

[3] Sheng Hu, Seventy years of the Chinese Communist Party[M],CPC History Press(1991),Page 333

[4] Selected works of Lenin Vol. second[M], People's Publishing House(1972),Page7 19

[5] Selected works of Zedong Mao Vol. sixth[M], People's Publishing House(1999),Page 80

[6] Selected works of Lenin Vol. Forty-first[M], People’s Publishing House(1986),Page 301 302

[7] Selected works of Xiaoping Deng Vol. second[M], People's Publishing House(1994),Page 302

[8] Selected readings of Marxism Leninism writings(scientific socialism)[M], People’s Publishing House(1988),Page 319

Author: Kangjian Shi, Male, born in 1958, doctoral candidate, associate professor. And his main research direction is Zedong Mao thought and socialist theory. 